\title{
The last of its kind? Radiocarbon, ancient DNA and stable isotope evidence from a late cave bear (Ursus spelaeus ROSENMÜLLER, 1794) from Rochedane (France)
}

\author{
Hervé Bocherens ${ }^{\mathrm{a}, *}$, Anne Bridault ${ }^{\mathrm{b}}$, Dorothée G. Drucker ${ }^{\mathrm{a}}$, Michael Hofreiter ${ }^{\mathrm{c}}$, \\ Susanne C. Münzel ${ }^{\mathrm{d}}$, Mathias Stiller ${ }^{\mathrm{e}}$, Johannes van der Plicht ${ }^{\mathrm{f}, \mathrm{g}}$ \\ ${ }^{a}$ Universität Tübingen, Fachbereich Geowissenschaften, Biogeologie, Hölderlinstrasse 12, Tübingen D-72074, Germany \\ ${ }^{\mathrm{b}}$ Équipe Archéologies environnementales, UMR $7041 \mathrm{ArScAn}$, Nanterre, France \\ ${ }^{\mathrm{c}}$ Department of Biology (Area 2), University of York, United Kingdom \\ ${ }^{\mathrm{d}}$ Universität Tübingen, Fachbereich Geowissenschaften, Naturwissenschaftliche Archäologie, Archäozoologie, Tübingen, Germany \\ e Department of Ecology and Evolutionary Biology, University of California Santa Cruz, Santa Cruz, USA \\ ${ }^{\mathrm{f}}$ Centre for Isotope Research, Groningen University, The Netherlands \\ ${ }^{\mathrm{g}}$ Faculty of Archaeology, Leiden University, The Netherlands
}

\section{A B S T R A C T}

We report here a new discovery of a cave bear left metatarsal 3 from Rochedane, an archaeological site near Montbeliard (French Jura) that yielded only Lateglacial and Holocene material, with no evidence of pre-LGM deposits, a context that made this bone a possible candidate for being a post-LGM cave bear in western Europe. To test this hypothesis, this bone was analyzed for mitochondrial DNA, which confirmed its attribution to cave bear of the Ursus spelaeus lineage, and a direct radiocarbon AMS dating on well preserved collagen $(\% \mathrm{C}, \% \mathrm{~N}$ and $\mathrm{C} / \mathrm{N}$ well in the range of fresh collagen) yielded an age of $23,900+110-100 \mathrm{BP}(28,730-28,500 \mathrm{cal} \mathrm{BP}$, one sigma range). Its carbon and nitrogen isotopic values were similar to those of slightly older cave bears from the Swabian Jura, around $300 \mathrm{~km}$ to the East, suggesting that the ecological preferences of cave bears remained unchanged until the extirpation of this species in western Europe. Interestingly, the genetic type U. spelaeus was replaced by Ursus ingressus around $28,000{ }^{14} \mathrm{C} \mathrm{BP}$ in the Swabian Jura. In contrast, the older type U. spelaeus apparently persisted in France ca. 3000 years longer. Traces left on the cave bear metapodium have been left by human activity on this bone, as it was the case for older cave bear bones from the Swabian Jura. This case study shows that cave bear remains found in post-LGM sites or layers may be candidates to be late survivors of this extinct species, but without direct radiocarbon AMS dated on well-preserved collagen (demonstrated by actual chemical composition results) and ancient DNA confirmation of the species attribution, such evidence can only be considered dubious.

\section{Introduction}

The Late Quaternary large mammal extinctions that took place between around 40,000 and 10,000 years ago in Europe are still a subject of intensive debate (e.g. Koch and Barnosky, 2006; Pushkina and Raia, 2008; Bridault and Chaix, 2009; Lorenzen et al., 2011; Prescott et al., 2012). Even fundamental aspects such as the timing of the extinctions, i.e. whether they took place before the Last Glacial Maximum (pre-LGM), at the end of the

\footnotetext{
* Corresponding author.

E-mail address: herve.bocherens@uni-tuebingen.de (H. Bocherens).
}

Pleistocene 12,000 years ago or later during the Holocene, are still under investigation. The ultimate causes that led to this large scale extinction, with humans and climate change being the main potential causes discussed, are not yet well understood. Both were probably playing a role, but to different extents for different species and in different areas (Prescott et al., 2012). In any case, a better understanding of the mechanisms that led to the extinction of several large mammal species in Europe in a context of climate instability and changing human impact on the ecosystems will have implications for anticipating possible future extinctions.

The cave bear (Ursus spelaeus) is a particularly interesting species to focus upon because it is probably the Late Quaternary 
mammal that yielded the largest amount of fossil material in Europe, with a large part associated with human deposits in archaeological sites. It is one of the large mammal species that disappeared during the last 30,000 years, but the exact time and cause of its extinction remain unclear (e.g. Stuart and Lister, 2007; Pacher and Stuart, 2009). Also, thanks to the very good general molecular preservation of cave bear bones in karst contexts, numerous studies dealing with stable isotopes of collagen and ancient DNA have yielded invaluable information about the palaeoecology and the phylogeography of this extinct species (e.g. Bocherens et al., 1994, 2006, 2011b; Hofreiter et al., 2002, 2007; Orlando et al., 2002; Stiller et al., 2010; Münzel et al., 2011). The combination of both approaches has also yielded interesting results about the population dynamics of this species in relationship with its ecological habits (e.g. Münzel et al., 2011; Bocherens et al., 2011b).

In the region including the French, Swiss, and German parts of the Jura Mountains, termed the northwestern alpine foreland in this paper, numerous cave bear bones have been recovered from archaeological layers attributed to the Magdalenian culture (Kurtén, 1976; Musil, 1981). Faunal remains from such contexts in this region are radiocarbon dated to between around 12,000 and 19,600 BP (13,800-23,900 years cal BP; Drucker et al., 2012). Magdalenian occupation of northwestern Europe started with the climatic warming following the Last Glacial Maximum (LGM) and probably ended with the climatic amelioration of the Greenland Interstadial GI-1e which coincided with a change in terrestrial ecosystems (Straus et al., 2012). However, evidence of cave bear survival after the LGM must be based on unambiguous taxonomic attribution, since the closely related brown bear (Ursus arctos) was present in this region at this time, and the chronological attribution must be established through direct radiocarbon dating of the same cave bear bones or teeth. Using mostly ancient DNA analysis and AMS radiocarbon dating of bone collagen, a number of alleged cave bear founds post-dating the LGM have been evaluated, and, although the taxonomic attribution was confirmed by palaeogenetic analysis, all of the studied samples yielded ${ }^{14} \mathrm{C}$ ages older than 24,000 BP (Table 1, Fig. 1). This apparent lack of evidence for cave bears younger than the LGM in the northwestern alpine foreland must be confirmed by further investigations of Magdalenian faunal assemblages in this region. In the present work, we report the result of such an investigation on one cave bear bone from a site in the French Jura, Rochedane, where so far the oldest archaeological layers contain evidence of the Magdalenian culture. We applied to this bone all the techniques that will allow us to fit this specimen into a chronological, phylogeographical and ecological context and yield further information that will help to understand the extinction process of cave bears in this region.

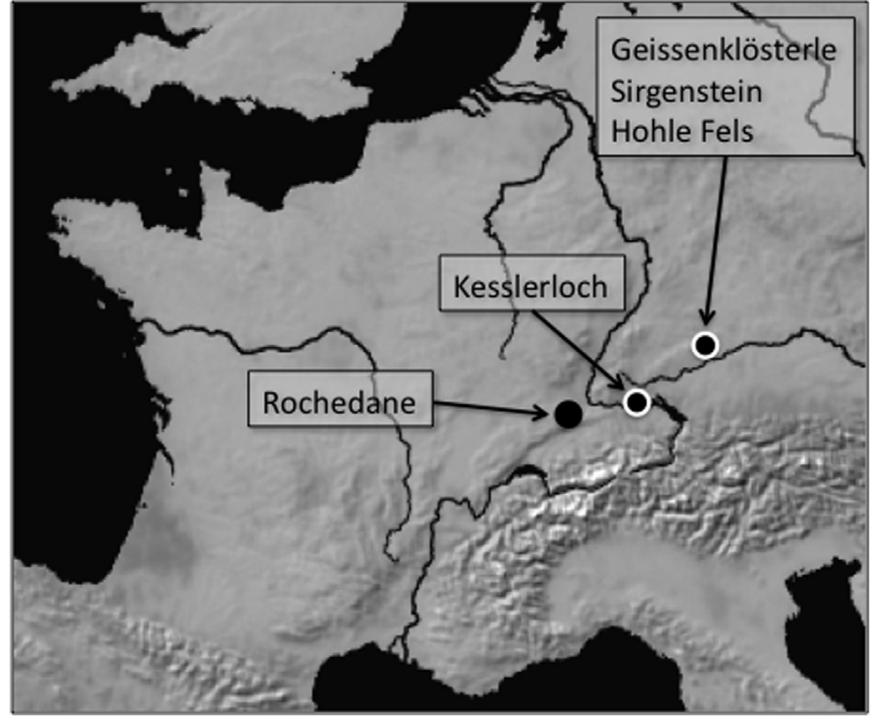

Fig. 1. Geographical location of sites with remains of cave bear supposedly associated with Magdalenian archaeological layers. The numbers correspond to sites from which cave bears for the osteometric comparisons come from: 1. Grotte de Vaucluse, 2. Grotte des Crosses, 3. Goyet, 4. Zoolithenhöhle-Spalte, 5. Hohle Fels, 6. Brillenhöhle VI, 7. Erpfingen, 8. Buse di Bernardo.

\section{Material}

The site of Rochedane $\left(47^{\circ} 21^{\prime} \mathrm{N}, 6^{\circ} 46^{\prime} \mathrm{E}\right)$ is located approx. $25 \mathrm{~km}$ south of the town of Montbeliard on the left bank of the Doubs River. It is a rock-shelter dug into a calcareous cliff about $15 \mathrm{~m}$ high, at an altitude of $355 \mathrm{~m}$ above sea level in an area where the neighboring plateaus rise to $700 \mathrm{~m}$ above sea level. Excavation of Rochedane by André Thévenin and Jean Sainty (1968-1976) identified several archaeological layers ranging between ca. 12,500 and 8000 BP (e.g. Thévenin, 1982; Thévenin and Sainty, 1998). The deepest archaeological layer (D1) yielded ${ }^{14} \mathrm{C}$ dates ranging from $12,235 \pm 85$ to $12,420 \pm 75 \mathrm{BP}$, but another layer called D2 without any archaeological artefact was also recognized below D1. A skeletal part attributed to cave bear, a third left metatarsal, was found outside a clear stratigraphical context, probably from D2 or lower levels (Fig. 2). An osteological examination suggested that this specimen had characteristics indicative of a cave bear $U$. spelaeus rather than of a brown bear $U$. arctos, present in the Holocene levels of the rock-shelter. As the archaeological excavation did not provide any evidence for pre-LGM deposits, this possible cave bear bone may be evidence of the post-LGM cave bear in Northeastern France. However, as many other similar occurrences proved to be older than expected, even in sites with no obvious evidence of deposits

Table 1

List of cave bear bones reported in post-LGM archaeological layers in the Northwestern alpine foreland. Italicized AMS $14 \mathrm{C}$ dating stands for discarded date due to poor collagen preservation.

\begin{tabular}{|c|c|c|c|c|c|c|}
\hline Site & Country & Piece & Archaeological context & Species (method) & Direct AMS ${ }^{14} \mathrm{C}$ dating (BP) & Reference \\
\hline Geißenklösterle & Germany & Maxilla (juvenile) & Magdalenian/Gravettian & Ursus ingressus (DNA) & $\begin{array}{l}13,230 \pm 130(\mathrm{OxA}-4854) \\
24,210 \pm 100(\mathrm{GrA}-39687)\end{array}$ & $\begin{array}{l}\text { Münzel et al. (2007) } \\
\text { Münzel et al. (2008) }\end{array}$ \\
\hline Geißenklösterle & Germany & 3rd upper incisor & Magdalenian/Gravettian & Ursus ingressus (DNA) & $26,740 \pm 120($ Beta-143244) & Münzel et al. $(2008,2011)$ \\
\hline Geißenklösterle & Germany & 3rd upper incisor & Magdalenian/Gravettian & Ursus ingressus (DNA) & $27,240 \pm 200$ (Beta-161019) & Münzel et al. $(2008,2011)$ \\
\hline Geißenklösterle & Germany & 2nd lower incisor & Magdalenian/Gravettian & Ursus ingressus (DNA) & $27,340 \pm 180($ Beta-161018) & Münzel et al. $(2008,2011)$ \\
\hline Geißenklösterle & Germany & 2nd lower incisor & Magdalenian/Gravettian & Ursus ingressus (DNA) & $27,870 \pm 190($ Beta-161020) & Münzel et al. $(2008,2011)$ \\
\hline Hohle Fels & Germany & 3rd upper incisor & Magdalenian? & Ursus ingressus (DNA) & $28,040 \pm 200($ Beta-161021) & Münzel et al. $(2008,2011)$ \\
\hline Sirgentein & Germany & 1st lower molar & Magdalenian? & Ursus ingressus (DNA) & $25,560 \pm 130(\mathrm{OxA}-12013)$ & Münzel et al. (2008) \\
\hline Sirgentein & Germany & 1st lower molar & Magdalenian? & Ursus ingressus (DNA) & $26,980 \pm 130(\mathrm{OxA}-12014)$ & Münzel et al. (2008) \\
\hline Sirgentein & Germany & 1st lower molar & Magdalenian? & Ursus ingressus (DNA) & $35,770 \pm 330(\mathrm{OxA}-12015)$ & Münzel et al. (2008) \\
\hline Kesslerloch & Switzerland & 2nd upper molar & Magdalenian? & $\begin{array}{l}\text { Ursus cf spelaeus } \\
\text { (morpho.) }\end{array}$ & $\begin{array}{l}36,400+420 /-400 \\
(\mathrm{KIA}-33349)\end{array}$ & Napierala (2008) \\
\hline
\end{tabular}



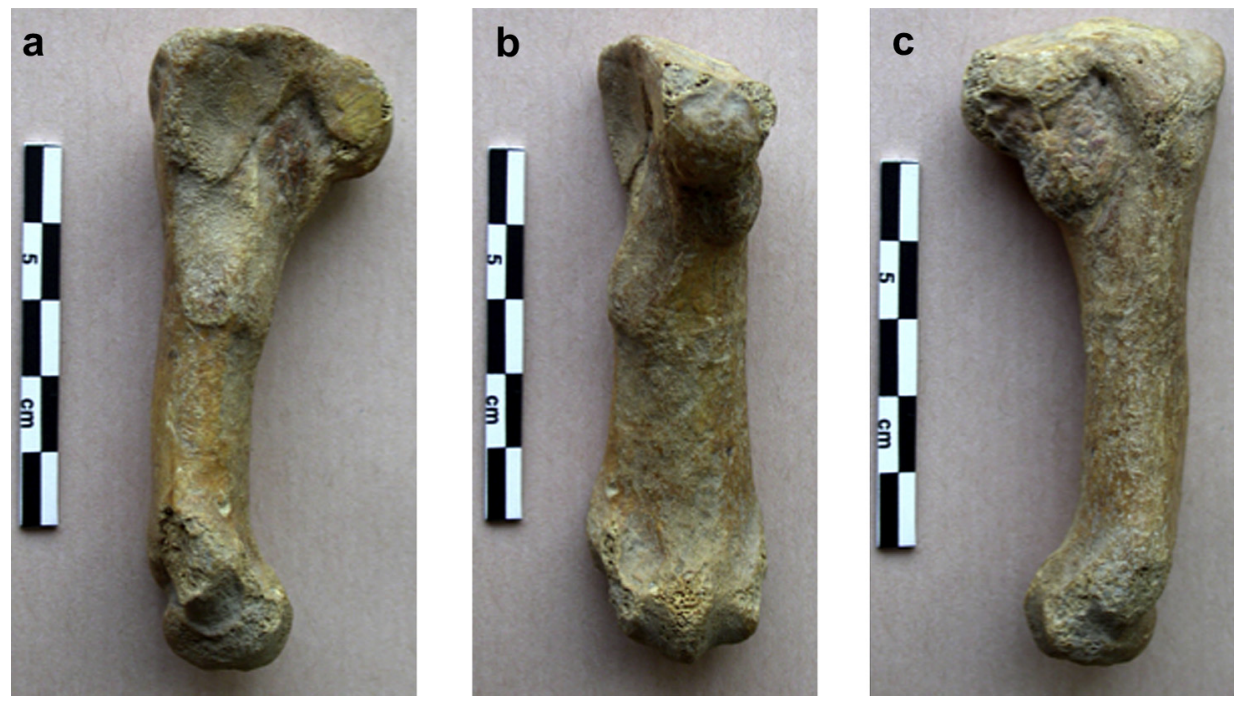

Fig. 2. Pictures of the studied bone: a and c: lateral views; b: ventral view.

older than the LGM, a complete analytical program was undertaken including taxonomical determination using osteometry and palaeogenetics, direct AMS radiocarbon dating, and stable isotopic tracking of palaeoecological parameters.

\section{Methods}

\subsection{Osteometry}

Cave bears are closely related to brown bears, both species showing large morphological variability due to different factors such as individual age, sexual dimorphism and geographical variation. Therefore, although many skeletal parts are similar in both bear species, it is possible to evaluate the range of variation for a given bone, in this case the third metatarsal, in order to identify the taxonomic status of the specimen.

To compare the size of the 3rd metatarsal from Rochedane, we used two combined measurements, the greatest length (GL) and the smallest breadth of diaphysis (SB), following Athen et al. (2005). As it is of general use, only fused specimens were taken into account, in order to eliminate variation due to lengthwise bone growth.

Cave bear assemblages from sites located in the circumscribed geographical areas mentioned above and included in a broad similar chronological range were selected for comparison (Fig. 1). The following caves are all radiocarbon dated to between ca. 40,000 and 25,000 ${ }^{14}$ C BP: Goyet (Condroz, Belgium); Hohle Fels, Erpfingen and Brillenhöhle (Baden-Württemberg, Germany); ZoolithenhölheSpalte (Bavaria, Germany); Buse di Bernardo (Trentino Alto Adige, Italy). Grotte des Crosses (Doubs, France) is attributed to the Upper Pleistocene. Grotte de Vaucluse, nearby Rochedane, has yielded the richest corpus of third metatarsals $(N=98)$ (Schweizer, 1999, 2005), but it is undated. The gathered data are listed in Table 2 .

Similar osteometric data are less numerous for brown bears and had to be collected from a larger sample of paleontological and archaeological sites located in various European areas (Table 3). Some data from reference collections (modern bears) were also added for comparison (Müller, 1971; Schweizer, 1999; Athen, 2007).
Bears, and particularly cave bears, display a strong sexual dimorphism (Grandal-d'Anglade, 2001). An unbalanced sex-ratio would then influence the average values of measurements in the distributions. Mixture analysis has proved to be a relevant method for sex determination when applied to cave bear assemblages (Quiles et al., 2005). "Mixture analysis is a maximum-likelihood method for estimating the parameters (mean, standard deviation and proportion) of two or more univariate normal distributions, based on a pooled univariate sample" (Hammer et al., 2001). It was applied here together with a normality statistical test (AndersonDarling) using the software Past (Hammer et al., 2001), in order to first analyze if each distribution could be derived from a population with normal distribution ( $\mathrm{HO}$ ) or biased by an unbalanced sex ratio. The only sample for which normal distribution can be rejected is Grotte Vaucluse. It is significantly biased in favor of the highest values $(71.5 \%$ and $77.5 \%$ for group\#2, Table S3.), for males (Table S3).

\subsection{Ancient DNA}

A subsample of $185 \mathrm{mg}$ was taken from the original metapodial specimen RCD10900cb that yielded the radiocarbon date. Ancient DNA was then extracted using a column based silica extraction protocol as described in Rohland et al. (2010). Extractions accompanied by negative controls were performed in a dedicated ancient DNA laboratory, physically separated from any post-PCR workspaces. We used $5 \mu \mathrm{l}$ of ancient DNA extract and primers $2670 \mathrm{a}\left(5^{\prime}-\right.$ CTATTTAAACTATTCCCTGGTACATAC-3') and 2719 (5'-ATGGGGGCACGCCATTAATGC- $3^{\prime}$ ) to generate a $165 \mathrm{bp}$ PCR product (117 bp excluding primer sequences). Primers and amplification conditions were adopted from Hofreiter et al. (2004b). The amplification reactions were done in replicates and negative controls included at all times. PCR products were then cloned using the TOPO TA cloning kit (Life Technologies) and 6 clones were Sanger sequenced on an ABI 3730 capillary sequencing instrument. We then aligned all clone sequences of both PCR replicates and called a consensus sequence using the software BioEdit (Hall, 1999).

Table 2

Chemical and isotopic characteristics of the Rochedane cave bear collagen.

\begin{tabular}{|c|c|c|c|c|c|c|c|c|c|c|c|}
\hline Species & Site & ${ }^{14} \mathrm{C}$ age & Age cal BP (1s) & Date no. & Lab no. & $\begin{array}{l}\text { Coll. yield } \\
\left(\mathrm{mg} \mathrm{g}^{-1}\right)\end{array}$ & $\% \mathrm{C}$ & $\% \mathrm{~N}$ & $\mathrm{C} / \mathrm{N}$ & $\Delta^{13} \mathrm{C}(\%)$ & $\delta^{15} \mathrm{~N}(\% \mathrm{o})$ \\
\hline Ursus spelaeus & Rochedane & $23,900+110 /-100$ & BP $28.730-28.500 \mathrm{cal}$ & BP GrA-52632 & RCD-10900cb & 21 & 37.1 & 13.4 & 3.2 & -21.0 & 4.6 \\
\hline
\end{tabular}




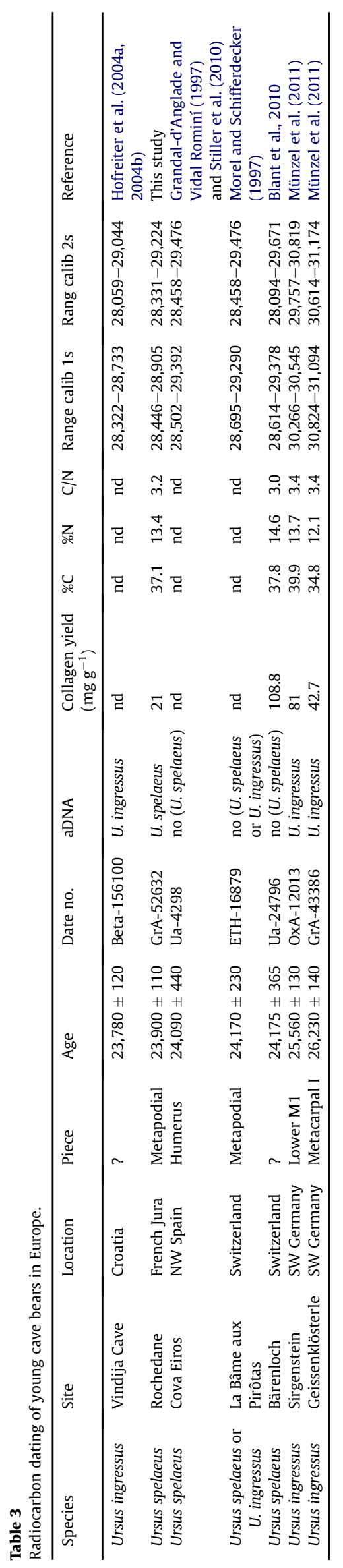

\subsection{Collagen extraction and stable isotopes}

A small bone fragment was carefully sawn on one side of the diaphysis of the metatarsus, ultrasonicated in acetone and water, rinsed with distilled water, dried and crushed to a powder of $0.7 \mathrm{~mm}$ grain size. The collagen was purified according to a well establish protocol (Bocherens et al., 1997). The elemental and isotopic measurements were performed at the Geochemical unit of the Geoscience Faculty at the University of Tübingen (Germany), using an elemental analyser NC 2500 connected to a Thermo Quest Delta + XL mass spectrometer. The isotopic ratios are expressed using the " $\delta$ " (delta) value as follows: $\delta^{13} \mathrm{C}=\left[\left({ }^{13} \mathrm{C} /{ }^{12} \mathrm{C}\right)_{\text {sample }} /\right.$ $\left.\left({ }^{13} \mathrm{C} /{ }^{12} \mathrm{C}\right)_{\text {reference }}-1\right] \times 1000 \%$ and $\delta^{15} \mathrm{~N}=\left[\left({ }^{15} \mathrm{~N} /{ }^{14} \mathrm{~N}\right)_{\text {sample }} /\right.$ $\left.\left({ }^{15} \mathrm{~N} /{ }^{14} \mathrm{~N}\right)_{\text {reference }}-1\right] \times 1000 \%$, with the international reference being V-PDB for $\delta^{13} \mathrm{C}$ values and atmospheric nitrogen (AIR) for $\delta^{15} \mathrm{~N}$ values. Measurements were normalized to $\delta^{13} \mathrm{C}$ values of USGS24 $\left(\delta^{13} \mathrm{C}=-16.00 \%\right.$ ) and to $\delta^{15} \mathrm{~N}$ values of IAEA $305 \mathrm{~A}$ $\left(\delta^{15} \mathrm{~N}=39.80 \%\right)$. The reproducibility was $\pm 0.1 \%$ or $\delta^{13} \mathrm{C}$ measurements and $\pm 0.2 \%$ for $\delta^{15} \mathrm{~N}$ measurements, based on multiple analyses of purified collagen from modern bones.

The reliability of the isotopic signatures of the collagen extracts was addressed using their chemical composition (\% , \%N, and $\mathrm{C} / \mathrm{N}$ ratios). These values must be similar to those of collagen extracted from fresh bone to be considered reliable for isotopic measurements and radiocarbon dating. Several studies have shown that collagen with atomic $\mathrm{C} / \mathrm{N}$ ratios lower than 2.9 or higher than 3.6 is altered or contaminated, and should be discarded, as well as extracts with \% $<5 \%$ (DeNiro, 1985; Ambrose, 1990).

\subsection{Radiocarbon dating}

Part of the collagen prepared for stable isotope analysis was used for radiocarbon dating. The collagen was combusted into $\mathrm{CO}_{2}$ using an Elemental Analyzer, coupled to an Isotope Ratio Mass Spectrometer (Aerts et al., 2001). Part of the $\mathrm{CO}_{2}$ was routed to a cryogenic trap to collect the samples for further processing for ${ }^{14} \mathrm{C}$ analysis. The $\mathrm{CO}_{2}$ was transferred into graphite powder by the reaction $\mathrm{CO}_{2}+2 \mathrm{H}_{2} \rightarrow 2 \mathrm{H}_{2} \mathrm{O}+\mathrm{C}$ at a temperature of $600^{\circ} \mathrm{C}$ and using Fe powder as catalyst. The graphite was then pressed into target holders for the ion source of the AMS. The AMS measured then the ${ }^{14} \mathrm{C} /{ }^{12} \mathrm{C}$ and ${ }^{13} \mathrm{C} /{ }^{12} \mathrm{C}$ ratios of the graphite (van der Plicht et al., 2000).

The ${ }^{14} \mathrm{C}$ age is reported as a conventional age, i.e. based on the Libby half-life value, oxalic acid as a reference and correction for isotopic fractionation using ${ }^{13} \mathrm{C} /{ }^{12} \mathrm{C}$ (van der Plicht and Hogg, 2006). The ${ }^{14} \mathrm{C}$ dates need to be calibrated into calendar ages. This is done by the recommended calibration curve Intcal09 (Reimer et al., 2009). The calibrated ages are reported in cal BP, which are calendar ages relative to $1950 \mathrm{AD}$.

\section{Results}

\subsection{Osteometry}

The greatest length (GL) of the Rochedane specimen is $80.3 \mathrm{~mm}$ while the shortest breadth (SB) is $17.4 \mathrm{~mm}$. Compared to the reference dataset (Grotte Vaucluse excluded), the bivariate plot clearly indicates that the metatarsal from Rochedane falls within the variation of cave bears and outside the range of variation for brown bears (Fig. 3). These species are well differentiated by their metatarsal width, which is larger in cave bears. Compared to the Grotte Vaucluse cave bear sample, the Rochedane individual falls within the group of values for males as defined by the mixture analysis (Fig. 4). 


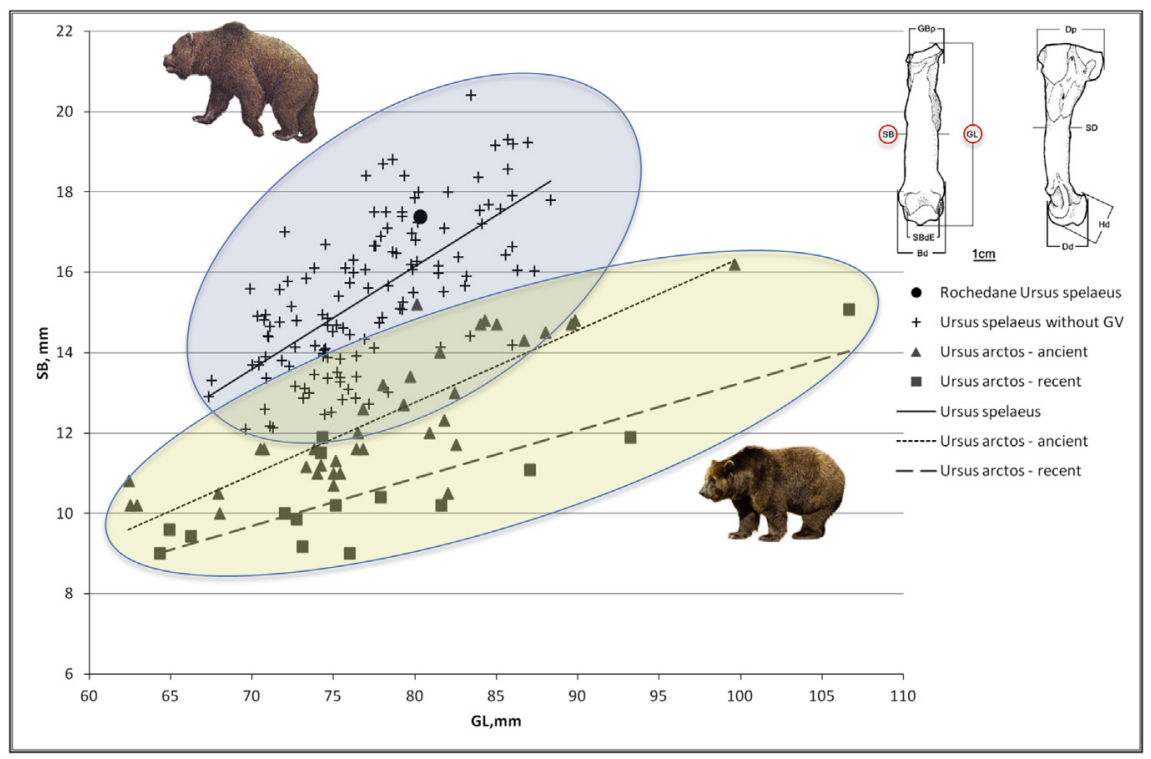

Fig. 3. Bivariate plot analysis - greatest length (GL, mm) and smallest breadth (SB, mm) of the third metatarsal - of cave bears from different sites (G. de Vaucluse excluded, Table. S1), brown bears from paleontological, archaeological sites ("ancient bears") and reference collections ("modern") listed in Table S2. The drawing showing how GL and SB were measured is from Athen (2007). (For interpretation of the references to colour in this figure legend, the reader is referred to the web version of this article.)
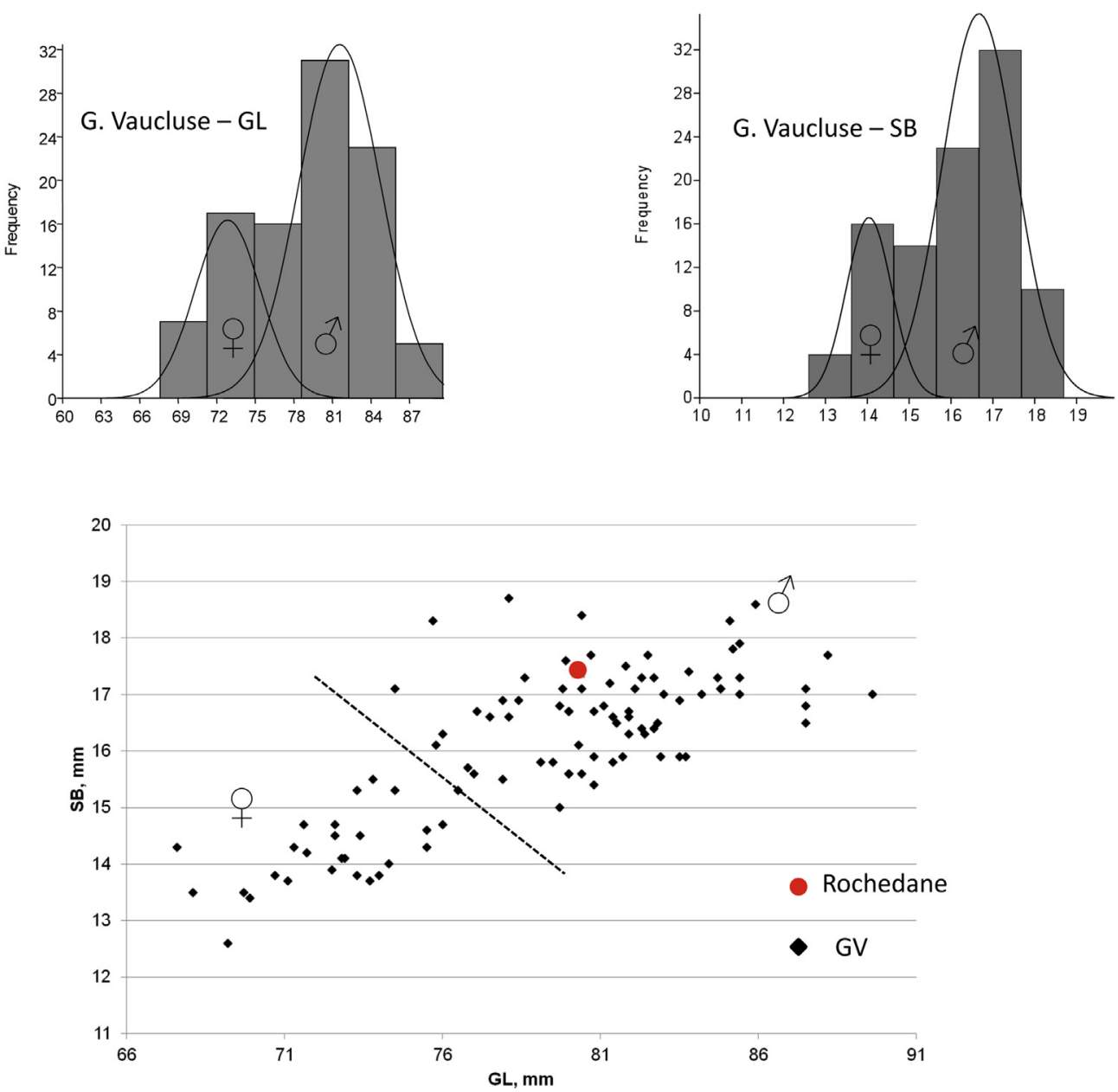

Fig. 4. Dimensions of the Rochedane third metatarsal compared to the specimens from Grotte de Vaucluse (Schweizer, 1999, 2005). Rochedane specimen fits in the values of males as defined by mixture analysis. 


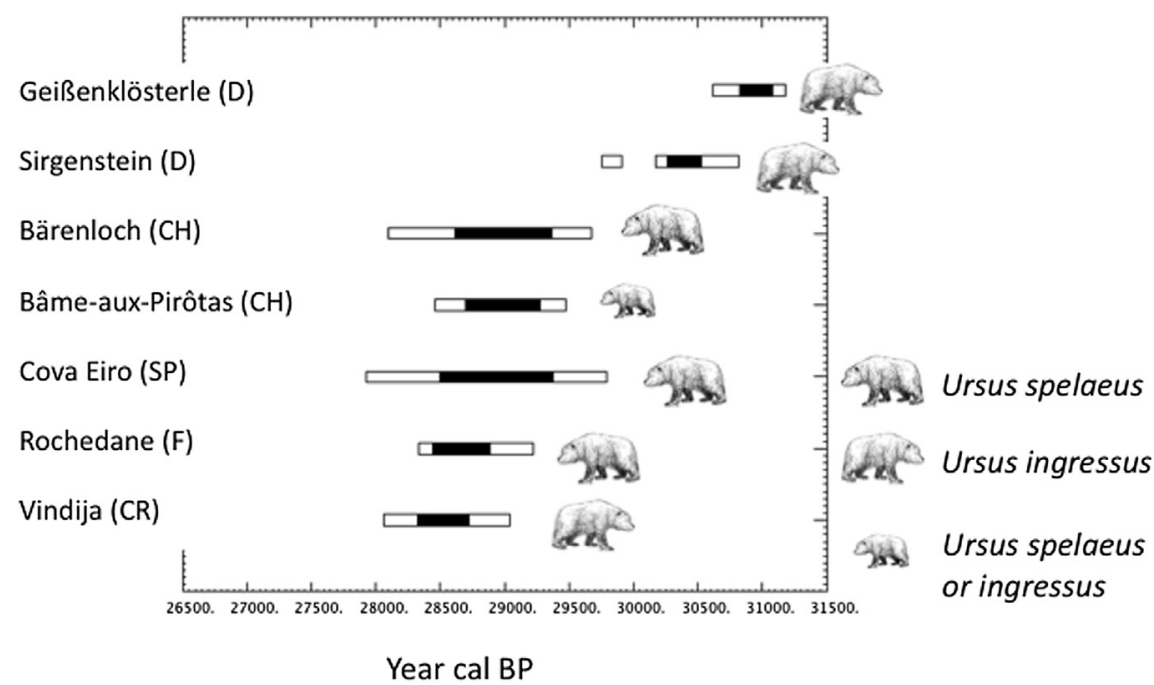

Fig. 5. Chronological position of Rochedane cave bears compared to other geologically young cave bears in Europe (range of calibrated dates using Calib 6.1 with INCAL09).

\subsection{Ancient DNA}

DNA preservation was sufficient to obtain a 117 bp sequence (165 bp including primers) of the mitochondrial control region with the following sequence: CATTATTTTACTCTATACCCTATTTATTTCA TATATACCATCTCATGTACTGTACCATCATAGTATGTCCTTAAATACTTTT TCCTTTATTTTTTTTTCCCCCCCTATGTATATCGT. A brief comparison to previously published sequence data using nucleotide blast (http://blast.ncbi.nlm.nih.gov/) clearly identified the specimen as cave bear rather than brown bear, confirming the taxonomic attribution based on the osteometric analysis. Specifically, the obtained mitochondrial DNA sequence belongs to the haplogroup $U$. spelaeus as opposed to the Ursus ingressus group. Both U. ingressus and $U$. spelaeus were present in the nearby Swabian Jura since 36,000 cal BP, but $U$. spelaeus disappeared from that area around 31,900 and 29,800 cal BP (Münzel et al., 2011), and only U. ingressus remained in the area until the final extinction of cave bears.

\subsection{Stable isotopes and radiocarbon dating}

The extracted collagen exhibits a chemical composition well within that of collagen extracted from fresh bone, with \% $\mathrm{C}=37.1 \%, \% \mathrm{~N}=13.4 \%$ and $\mathrm{C} / \mathrm{N}=3.2$. It is therefore considered reliable in terms of carbon and nitrogen stable isotopic composition and radiocarbon dating (Table 2 ). The $\delta^{13} \mathrm{C}$ value is $-21.0 \%$

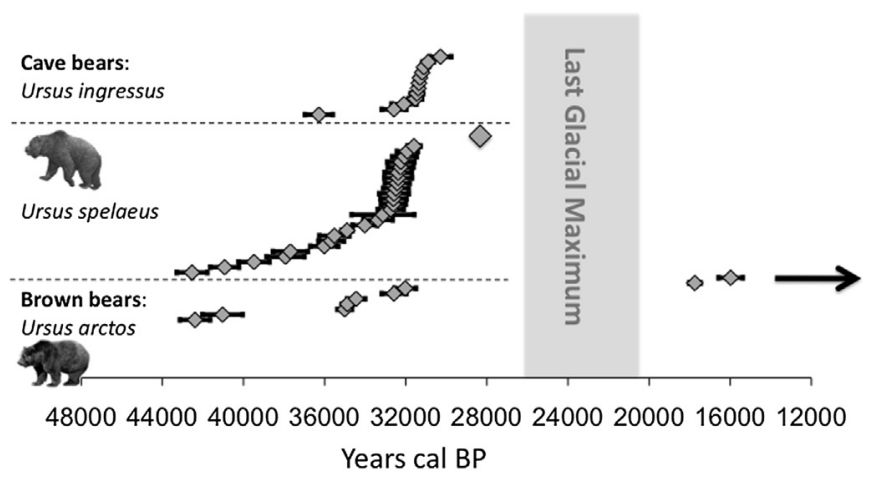

Fig. 6. Chronological position of Rochedane cave bears compared to other radiocarbon dated bears in the region (modified from Münzel et al., 2011). The radiocarbon dates have been calibrated according to Reimer et al. (2009). and the $\delta^{15} \mathrm{~N}$ value is $4.6 \%$. The radiocarbon age is measured as $23,900+110 /-100 \mathrm{BP}$. The calibrated age range is $28,730-$ 28,500 cal BP (1 sigma range).

\section{Discussion}

There is no doubt that the studied bone from Rochedane belongs to a cave bear and not to a brown bear. The results of the osteometric analysis unambiguously place the studied specimen within the range of the variation of the cave bears, most probably males, and rules out brown bears. The palaeogenetic analysis fully confirms this conclusion and furthermore indicates that this specimen belongs to the haplogroup $U$. spelaeus and not to $U$. ingressus (Münzel et al., 2011).

Radiocarbon dating shows that the age of the specimen is clearly older than the age range for the Magdalenian culture. Therefore, this cave bear is an additional case of a cave bear bone that does not belong to the cultural level it could (loosely) be associated with. In this case, there was no direct information that it came from a Magdalenian layer rather than from some other place not recognized in the site. However, the date is the youngest one so far recorded in the region, about 1000 years younger than the most recent radiocarbon date recorded in the Swabian Jura (around 29,700 cal BP; Münzel et al., 2011). Compared to the radiocarbon dates obtained from identified cave bear bones, the date of the Rochedane cave bear appears the second youngest one. The youngest one is from Vindija cave dated to $23,780 \pm 120 \mathrm{BP}$ (Hofreiter et al., 2004a). Three other directly dated cave bears, one from Spain and two from Switzerland, follow close behind (Table 3). After calibration and taking the standard deviations into account, all these cave bear bones yield age ranges that cannot be distinguished statistically (Fig. 5).

However, not all these radiocarbon dates are equally trustworthy. For instance, the radiocarbon dating of the Vindija cave bear is given without reliability criteria, and bones from this site have proven difficult to date due to poor collagen preservation (Higham et al., 2006). Therefore this date has to be taken with caution, and new dates on cave bear bones from this site should be undertaken with reliability criteria to confirm the occurrence of such young cave bears in Croatia. As well, the radiocarbon dates from Cova Eiros (Spain) and Bâme-aux-Pirôtas (Switzerland) were published without reliability criteria (Grandal-d'Anglade and Vidal Rominí, 1997; Morel and Schifferdecker, 1997). Only the 


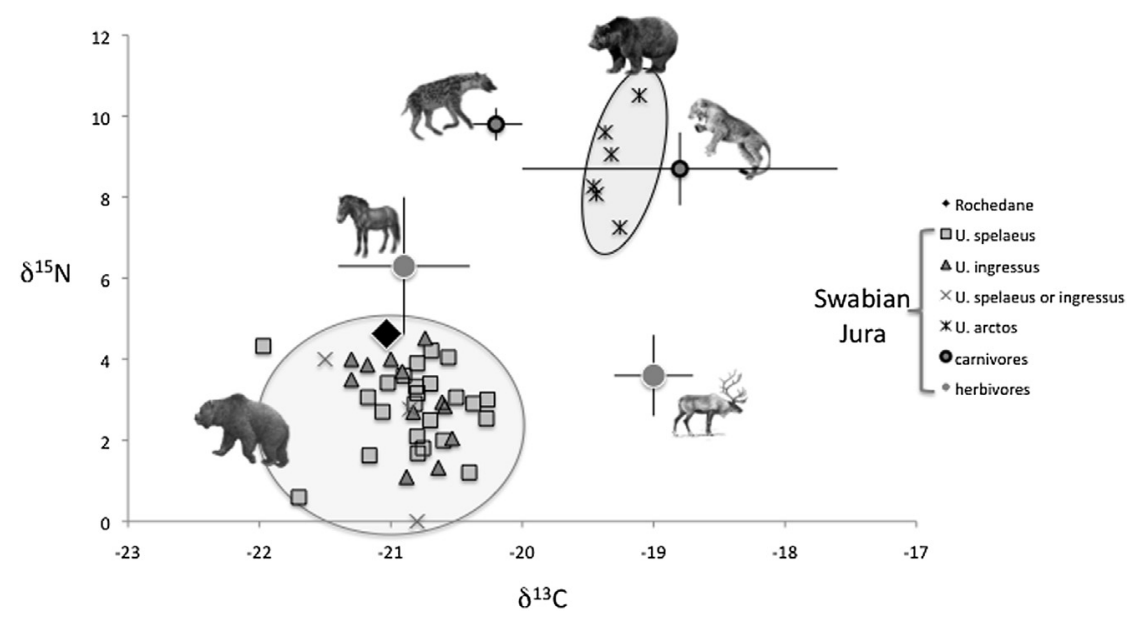

Fig. 7. $\delta^{13} \mathrm{C}$ and $\delta^{15} \mathrm{~N}$ values of Rochedane cave bear compared to pre-LGM mammals from the Swabian Jura (data from Bocherens et al., 2011a, 2011b).

radiocarbon dated cave bear from Bärenloch fulfills the criteria for reliability (Table 3 ).

The genetic type of these young cave bears is not always known by direct palaeogenetic investigations, but some inferences can be made using morphological features or using genetic information on specimens from the same layer. For instance, the study of the teeth of the cave bears from Bärenloch suggests that they belong to the $U$. spelaeus lineage (Blant et al., 2010), and we can assume that the dated specimen also belongs to this lineage. In the case of the dated specimen from Cova Eiros, one cave bear specimen from the same stratigraphic unit was studied palaeogenetically. It belongs to the $U$. spelaeus lineage (Stiller et al., 2010), and thus we can reasonably assume that is also the case for the dated specimen. However, the genetic lineage of the specimen from Bâme-aux-Pirôtas has not been investigated. It is not known whether it belongs to $U$. spelaeus or $U$. ingressus. Further research should clarify this point. In any case, it would be ideal to have a direct palaeogenetic investigation on the same bone as the one dated, as changes of genetic types are known to occur in sites in relatively short periods (Hofreiter et al., 2007; Münzel et al., 2011). In conclusion, the Rochedane cave bear is so far the only one among the most recent representatives of this species for which direct AMS radiocarbon dating with reliability criteria as well as palaeogenetic investigations have been performed on the same bone.

In the regional context of cave bear population dynamics, which is well documented in Southwestern Germany (Hofreiter et al., 2007; Münzel et al., 2011), the Rochedane cave bear appears unusual since the lineage $U$. spelaeus, to which the Rochedane cave bear belongs, disappears two thousand years before the lineage $U$. ingressus. If we broaden the region to include the Swiss Jura, the cave bear from Bärenloch, which seems to belong to $U$. spelaeus and is contemporaneous with the cave bear from Rochedane, supports the scenario that 1) cave bear populations were isolated between the Swabian Jura on one side and the French and Swiss Jura on the

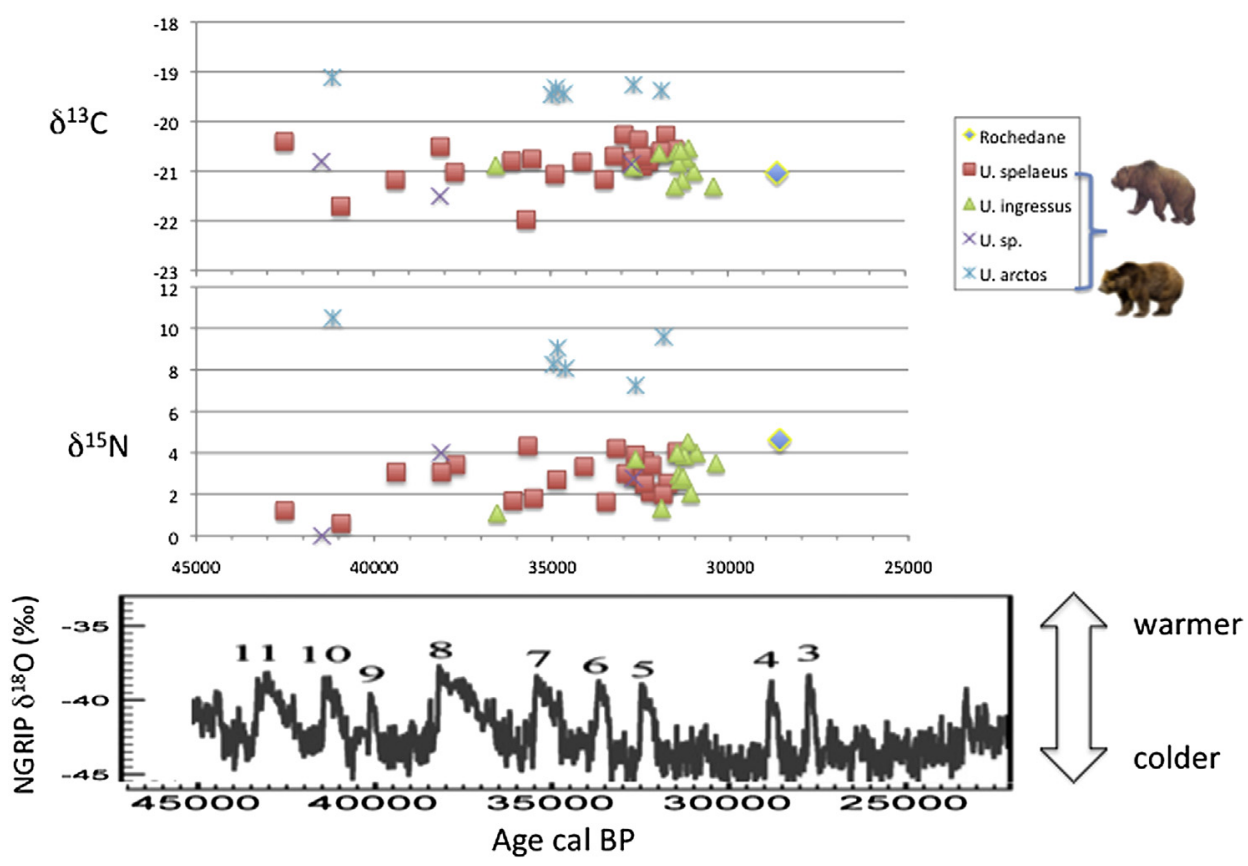

Fig. 8. Chronological trend in the $\delta^{13} \mathrm{C}$ and $\delta^{15} \mathrm{~N}$ values of bears in cave bears and brown bears from French and Swabian Jura. (For interpretation of the references to colour in this figure legend, the reader is referred to the web version of this article.) 


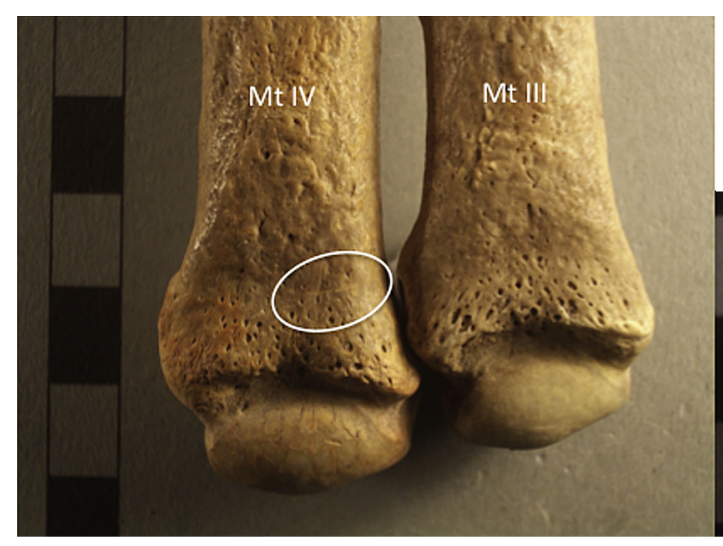

Cut mark on Mt IV from Hohle Fels

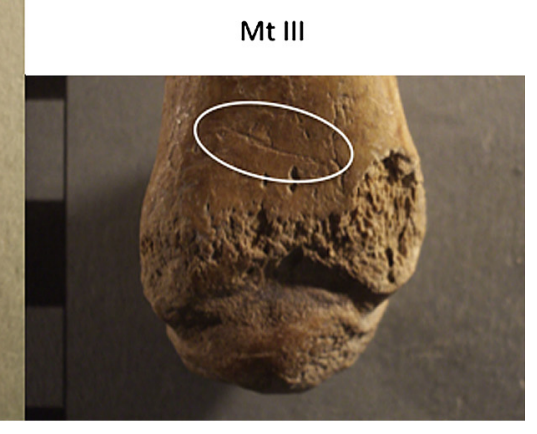

Cut mark on Mt III from Rochedane

Fig. 9. Possible cut-marks on the Rochedane cave bear metatarsal compared to those observed on similar bones from Hohle Fels.

other side, and 2) the lineage $U$. spelaeus survived longer East and South of the Rhine river than $U$. spelaeus and thereafter $U$. ingressus on the other side of the Rhine river (Fig. 6). Such a pattern suggests that, during the last thousand years of cave bear occurrences in the northwestern alpine foreland, the different populations were fragmented, and that some local extirpation occurred, sometimes with re-immigration of cave bears in the same area, as shown by the replacement of $U$. spelaeus by $U$. ingressus in the Swabian Jura, or without re-immigration of this species, as it was probably the case in the French Jura after 28,500 cal BP.

Considering that the cave bear from Rochedane thus far is the youngest one known from this region, it is of interest to study the stable carbon and nitrogen isotope ratios. This enables us to investigate whether this late surviving individual exhibits any change in its ecological habits compared to older specimens of the same species in the region, namely cave bears from the Swabian Jura which have been studied extensively (Münzel et al., 2011). When plotted together with representatives of large mammal species in the Swabian Jura prior to the LGM, including cave bears as well as herbivores such as horse and reindeer, and predatory carnivores, such as hyenas and lions, the cave bear from Rochedane plots together with the vegetarian cave bears and very differently from the carnivorous brown bears (Fig. 7). This indicates that the cave bear from Rochedane did not differ in its dietary habits from the pattern of the species in western and central Europe, an essentially vegetarian diet (e.g. Bocherens et al., 1994, 1997, 2006, 2011a; Mosquera, 1998; Blant et al., 2010; Pacher et al., 2012).

However, the cave bear from Rochedane exhibits one of the most positive $\delta^{15} \mathrm{~N}$ values in comparison with the cave bears from the Swabian Jura, which could indicate an ecological shift. To test this hypothesis, we plotted all isotopic values for directly radiocarbon dated cave bears and brown bears from the Swabian Jura and Rochedane (Fig. 8). This graph does not show any clear trend in either $\delta^{13} \mathrm{C}$ or $\delta^{15} \mathrm{~N}$ values during the last thousand years of occurrence of cave bears in the northwestern alpine foreland. The $\delta^{13} \mathrm{C}$ values range from around -22 to $-20 \%$, while the $\delta^{15} \mathrm{~N}$ values range from around 0 to $5 \%$, which is similar to the range exhibited by herbivorous species in the same region during the same period (Bocherens et al., 2011a). This suggests that cave bears did not change significantly their ecology during this period. The youngest cave bear from Rochedane presents $\delta^{13} \mathrm{C}$ and $\delta^{15} \mathrm{~N}$ values similar to those measured in cave bears more than 10,000 years older in the same region, suggesting a relative ecological stability for this species in the region. It is not possible to correlate the fluctuations of $\delta^{13} \mathrm{C}$ and $\delta^{15} \mathrm{~N}$ values with climatic oscillations due to the standarddeviation of calibrated radiocarbon dates, which are larger than the duration of interstadial episodes during this period. For the same reason, it is not possible to compare this last occurrence of cave bear in the French Jura with the global climatic context as recorded in Greenland ice, as it could fit either GS-4 or GI-4 using the terminology of Blockley et al. (2012). In any case, it seems that the last documented occurrence of cave bear in the region predates the extension of ice caps on the Jura Mountains by around 1000 years, since this initial glacial expansion is estimated to date to around 28,000 cal BP (Buoncristiani and Campy, 2004).

A final observation made on the metatarsal bone of the Rochedane cave bear suggests that humans may have had an impact in the final demise of the species in the region. A possible cut-mark was identified on the distal end of the metatarsal, in a very similar position as cut-marks observed on metatarsal bones from cave bears in Hohle Fels, where several evidence of human treatment of cave bear bones have been recognized (Münzel and Conard, 2004) (Fig. 9). Cut-marks in this position suggest skinning of the bear for fur exploitation (Münzel and Conard, 2004; Münzel et al., 2011). We cannot infer from this observation that humans were directly responsible for the death of this cave bear individual, but such a cut-mark indicates that cave bears were part of the prey spectrum of Upper Palaeolithic humans on both sides of the Rhine River, a situation that was probably not favorable to the survival of the species.

\section{Conclusion}

The cave bear from Rochedane demonstrates once more that the mere occurrence of cave bear remains in Magdalenian archaeological layers is not enough to demonstrate post-LGM survival of this species. Such claims need further confirmation 1) of the taxonomic attribution of the skeletal remains to cave bears by unambiguous morphological analysis and, as much as possible, by ancient DNA, which provides a secure specific attribution and a determination of the genetic type, and 2) by direct AMS dating to establish the chronological context.

The late cave bear in Rochedane belongs to haplogroup $U$. spelaeus that disappeared earlier in SW Germany (it is replaced by newer type $U$. ingressus). This indicates that cave bears occurred as fragmented populations across the Rhine with no genetic interchange between them. The cave bear from Rochedane is about 3000 years younger than the youngest $U$. spelaeus in SW Germany 
and 2000 years younger than any cave bear in SW Germany. The youngest cave bear in French Jura occurred shortly before ice sheets extended at the beginning of the LGM in the Jura Mountains. However, its $\delta^{13} \mathrm{C}$ and $\delta^{15} \mathrm{~N}$ values do not show any obvious ecological change since 40,000 years cal BP despite climatic fluctuations, suggesting a strong niche conservatism for this species, leading to a possible lack of ecological flexibility in the face of climate change. However, cave bears survived previous similar climatic changes during the Pleistocene. What was different around ca. 24,000 years ago that could have led to their demise? We found on the bone of the Rochedane cave bear some evidence of human impact. We can speculate that a combination of climatic deterioration and increasing human pressure could explain the extirpation of cave bears in Northwestern alpine foreland, on already fragmented populations. This scenario is unfortunately very similar to the situation of numerous mammal species nowadays.

\section{Acknowledgements}

Thanks are due to Silviu Constantin for his kind invitation to the 18th International Cave Bear Conference in Baile Herculane (Romania), Bernd Steinhilber and Heinrich Taubald for technical assistance in stable isotope analysis, Aurora Grandal-d'Anglade for supplementary information on dated cave bears from Galicia (Spain), M. Schweizer for providing unpublished osteometrical data and J.E. Brochier for his comments on statistical analysis, and the Max Planck Society for financial support.

\section{Appendix A. Supplementary data}

Supplementary data related to this article can be found at http:// dx.doi.org/10.1016/j.quaint.2013.05.021

\section{References}

Aerts, A.T., van der Plicht, J., Meijer, H.A.J., 2001. Automatic AMS sample combustion and $\mathrm{CO}_{2}$ collection. Radiocarbon 43, 293-298.

Ambrose, S.H., 1990. Preparation and characterization of bone and tooth collagen for isotopic analysis. Journal of Archaeological Science 17, 431-451.

Athen, K., 2007. Biometrische Untersuchungen des Stylopodiums, Zygopodiums und Metapodiums pleistozäner Ursiden im Hinblick auf die Evolution des Höhlenbären und die Klassifizierung des Fundmaterials Einhornhöhle/ Harz. Dissertation zur Erlangung des Grades eines Doktors der Naturwissenschaften der Geowissenschaftlichen Fakultät der Eberhard-KarlsUniversität Tübingen. http://tobias-lib.uni-tuebingen.de/volltexte/2007/ 2893/pdf/Athen_Dissertation2007.pdf.

Athen, K., Frömke, C., Germonpré, M., 2005. Analysis of postcranial elements of cave bear material (Ursus spelaeus) from Goyet (Condroz/Belgium). Bulletin de l'Institut Royal des Sciences Naturelles de Belgique, Sciences de la Terre 75, 267-283.

Blant, M., Bocherens, H., Bochud, M., Braillard, L., Constandache, M., Jutzet, J.-M., 2010. Le gisement à faune Würmienne du Bärenloch (Préalpes fribourgeoises). Bulletin de la Société fribourgeoise des sciences naturelles SFSN 99, 1-22.

Blockley, S.P.E., Lane, C.S., Hardiman, M., Rasmussen, A.O., Seierstad, I.K., Steffensen, J.P., Svensson, A., Lotter, A.F., Turney, C.S.M., Bronk Ramsey, C., INTIMATE Members, 2012. Quaternary Science Reviews 36, 2-10.

Bocherens, H., Fizet, M., Mariotti, A., 1994. Diet, physiology and ecology of fossil mammals as inferred by stable carbon and nitrogen isotopes biogeochemistry: implications for Pleistocene bears. Palaeogeography, Palaeoclimatology, Palaeoecology 107, 213-225.

Bocherens, H., Billiou, D., Patou-Mathis, M., Bonjean, D., Otte, M., Mariotti, A., 1997. Paleobiological implications of the isotopic signatures $\left({ }^{13} \mathrm{C},{ }^{15} \mathrm{~N}\right)$ of fossil mammal collagen in Scladina Cave (Sclayn, Belgium). Quaternary Research 48, 370-380.

Bocherens, H., Drucker, D.G., Billiou, D., Geneste, J.-M., van der Plicht, J., 2006. Bears and Humans in Chauvet Cave (Vallon-Pont-d'Arc, Ardèche, France): insights from stable isotopes and radiocarbon dating of bone collagen. Journal of Human Evolution 50, 370-376.

Bocherens, H., Drucker, D.G., Bonjean, D., Bridault, A., Conard, N.J., Cupillard, C., Germonpré, M., Höneisen, M., Münzel, S.C., Napierrala, H., Patou-Mathis, M., Stephan, E., Uerpmann, H.-P., Ziegler, R., 2011a. Isotopic evidence for dietary ecology of cave lion (Panthera spelaea) in North-western Europe: prey choice, competition and implications for extinction. Quaternary International 245, 249-261.
Bocherens, H., Stiller, M., Hobson, K.A., Pacher, M., Rabeder, G., Burns, J.A., Tütken, T., Hofreiter, M., 2011b. Niche partitioning between two sympatric genetically distinct cave bears (Ursus spelaeus and Ursus ingressus) and brown bear (Ursus arctos) from Austria: isotopic evidence from fossil bones. Quaternary International 245, 238-248.

Bridault, A., Chaix, L., 2009. Réflexions sur la recomposition des spectres fauniques dans le massif jurassien et les Alpes françaises du nord durant le Tardiglaciaire. In: Mémoire L de la Société préhistorique française, pp. 59-71.

Buoncristiani, J.F., Campy, M., 2004. Expansion and retreat of the Jura ice sheet (France) during the last glacial maximum. Sedimentary Geology 165, 253264.

DeNiro, M.J., 1985. Postmortem preservation and alteration of in-vivo bone collagen isotope ratios in relation to palaeodietary reconstruction. Nature 317 , 806-809.

Drucker, D.G., Bridault, A., Cupillard, C., 2012. Environmental context of the Magdalenian settlement in the Jura Mountains using stable isotope tracking $\left({ }^{13} \mathrm{C},{ }^{15} \mathrm{~N},{ }^{34} \mathrm{~S}\right)$ of bone collagen from reindeer (Rangifer tarandus). Quaternary International 272-273, 322-332.

Grandal-d'Anglade, A., 2001. A review of the cave bear sex dimorphism. Cadernos do Laboratorio Xeolóxico de Laxe 26, 399-405.

Grandal-d'Anglade, A., Vidal Romaní, J.R., 1997. A population study of the cave bear (Ursus spelaeus Ros.-Hein.) from Cova Eirós (Triacastela, Galicia, Spain). Geobios 30, 723-731.

Hall, T.A., 1999. BioEdit: a user-friendly biological sequence alignment editor and analysis program for Windows 95/98/NT. Nucleic Acids Symposium Series 41, 95-98.

Hammer, Ø., Harper, D.A.T., Ryan, P.D., 2001. PAST: paleontological statistics software package for education and data analysis. Palaeontologia Electronica 4 (1), 9.

Higham, T., Bronk Ramsey, C., Karavanic, I., Smith, F.H., Trinkaus, E., 2006. Revised direct radiocarbon dating of the Vindija $G_{1}$ Upper Paleolithic Neandertals. PNAS 103, 553-557.

Hofreiter, M., Capelli, C., Krings, M., Waits, L., Conard, N., Münzel, S., Rabeder, G., Nagel, D., Paunovic, M., Jambresic, G., Meyer, S., Weiss, G., Pääbo, S., 2002. Ancient DNA analyses reveal high mitochondrial DNA sequence diversity and parallel morphological evolution of late Pleistocene cave bears. Molecular Biology and Evolution 19, 1244-1250.

Hofreiter, M., Rabeder, G., Jaenicke-Després, V., Withalm, G., Nagel, D., Paunovic, M., Jambresic, G., Pääbo, S., 2004a. Evidence for reproductive isolation between cave bear populations. Current Biology 14, 40-43.

Hofreiter, M., Serre, D., Roland, N., Rabeder, G., Nagel, D., Conard, N., Münzel, S., Pääbo, S., 2004b. Lack of phylogeography in European mammals before the last glaciation. Proceedings of the National Academy of Sciences of the United States of America 101, 12963-12968.

Hofreiter, M., Münzel, S., Conard, N., Pollark, J., Slatkin, M., Weiss, G., Pääbo, S., 2007. Sudden replacement of cave bear mitochondrial DNA in the late Pleistocene. Current Biology 17, R122-R123.

Koch, P.L., Barnosky, A.D., 2006. Late Quaternary extinctions: state of the debate. Annual Review of Ecology and Evolutionary Systems 37, 215-250.

Kurtén, B., 1976. The Cave Bear Story, Life and Death of a Vanished Animal. Columbia University Press, New York, p. 163.

Lorenzen, E.D., et al., 2011. Species-specific responses of Late Quaternary megafauna to climate and humans. Nature 479, 359-364.

Morel, Ph., Schifferdecker, F., 1997. Homme et ours des cavernes (Ursus spelaeus) au Pléistocène supérieur dans les grottes de l'Arc jurassien de Suisse occidentale: bilan et nouvelles données chronologiques. In: Proceedings of the 12th International Congress of Speleology. La Chaux-des-Fonds, Switzerland 10th-17th August 1997, vol. 3, pp. 137-140.

Mosquera, F.D., 1998. Isotopic biogeochemistry $\left(\delta^{13} \mathrm{C}, \delta^{15} \mathrm{~N}\right)$ of cave bear (Ursus spelaeus) from Cova Eiros site, Lugo (in Spanish). Cadernos do Laboratorio Xeolóxico de Laxe 23, 237-249.

Müller, H.-H., 1971. Der Braunbär - Ursus arctos L. - im Mittelalter. Hercynia 8 (1), 52-57.

Münzel, S.C., Conard, N.J., 2004. Cave bear hunting in the Hohle Fels, a cave site in the Ach Valley, Swabian Jura. Revue de Paléobiologie 23, 877-885.

Münzel, S.C., Hofreiter, M., Rabeder, G., Bocherens, H., Uerpmann, H.P., Conard, N.J., 2007. Correlating Genetic Results for the Replacement of Cave Bears at 28,000 B.P. from the Ach Valley (Swabian Jura) with Metrical and Morphological Data, vol. 35. Scripta, Faculty of Science, National University of Masaryk, Brno, pp. $123-128$.

Münzel, S.C., Hofreiter, M., Stiller, M., Conard, N.J., Bocherens, H., 2008. Neue Ergebnisse zur Paläobiologie der Höhlenbären auf der Schwäbischen Alb (Chronologie, Isotopie und Paläogenetik). Stalactite 58, 27-30.

Münzel, S.C., Hofreiter, M., Stiller, M., Mittnik, A., Conard, N.J., Bocherens, H., 2011. Pleistocene bears in the Swabian Jura (Germany): genetic replacement, ecological displacement, extinctions and survival. Quaternary International 245, 225-237.

Musil, R., 1981. Ursus spelaeus. Der Höhlenbär III. In: Weimarer Monographien zur Ur- und Frühgeschichte, vol. 2, pp. 1-112.

Napierala, H., 2008. Die Tierknochen aus dem Kesslerloch. Neubearbeitung der paläolithischen Fauna. In: Beiträge zur Schaffhauser Archäologie, pp. 1-128.

Orlando, L., Bonjean, D., Bocherens, H., Thenot, A., Argant, A., Otte, M., Hänni, C., 2002. Ancient DNA and the population genetics of cave bears (Ursus spelaeus) through space and time. Molecular Biology and Evolution 19, 1920-1933.

Pacher, M., Stuart, A.J., 2009. Extinction chronology and palaeobiology of the cave bear (Ursus spelaeus). Boreas 38, 189-206. 
Pacher, M., Bocherens, H., Döppes, D., Frischauf, C., Rabeder, G., 2012. First results of stable isotopes from Drachenloch and Wildenmannlisloch, Swiss Alps. Braunschweiger Naturkundliche Schriften 11, 101-110.

Prescott, G.W., Williams, D.R., Balmford, A., Green, R.E., Manica, A., 2012. Quantitative global analysis of the role of climate and people in explaining Late Quaternary megafaunal extinctions. Proceedings of the National Academy of Sciences of the United States of America 109, 4527-4531.

Pushkina, D. Raia, P. 2008. Human influence on distribution and extinctions of the late Pleistocene Eurasian megafauna. Journal of Human Evolution 54, 769-782.

Quiles, J., Monchot, H., Pacher, M., 2005. Mixture analysis: application to cave bear sex-ratio determination. Bulletin, Societe Histoire Naturalle Toulouse 141 (1), 29-37.

Reimer, P.J., Baillie, M.G.L., Bard, E., Bayliss, A., Beck, J.W., Blackwell, B.G., Bronk Ramsey, C., Buck, C.E., Burr, G.S., Edwards, R.L., Friedrich, M., Grootes, P.M. Guilderson, T.P., Hajdas, I., Heaton, T.J., Hogg, A.G., Hughen, K.A., Kaiser, K.F., Kromer, B., McCormac, F.G., Manning, S.W., Reimer, R.W., Richards, D.A. Southon, J.R., Talamo, S., Turney, C.S.M., van der Plicht, J., Weyhenmeyer, C.E. 2009. INTCAL09 and MARINE09 radiocarbon age calibration curves, $0-50,000$ years CAL BP. Radiocarbon 51, 1111-1150.

Rohland, N., Siedel, H., Hofreiter, M., 2010. A rapid column-based ancient DNA extraction method for increased sample throughput. Molecular Ecology Resources $10(4)$, 677-683.

Stiller, M., Baryshnikov, G., Bocherens, H., Grandal d'Anglade, A., Hilpert, B. Münzel, S.C., Pinhasi, R., Rabeder, G., Rosendahl, W., Trinkaus, E., Hofreiter, M. Knapp, M., 2010. Withering away - 25,000 years of genetic decline preceded cave bear extinction. Molecular Biology and Evolution 27, 975-978.
Schweizer, M., 1999. Étude d'une population d'ours des cavernes (Ursus spelaeus Rosenmüller \& Heinroth, 1794) provenant de la grotte de Vaucluse (Doubs, France). In: Travail de diplôme du Département d'Anthropologie et d'Écologie de l'Université de Genève, 2 vols., 270 pp. et 115 pp.

Schweizer, M., 2005. Étude des caractères non-métriques dans une population d'ours des cavernes (Ursus spelaeus ROSENMÜLLER \& HEINROTH, 1794) provenant de la grotte de Vaucluse (Doubs, France). Revue de Paléobiologie. Vol. spéc. 10, 3-9.

Straus, L.G., Leesch, D., Tielberger, T., 2012. The Magdalenian settlement of Europe: an introduction. Quaternary International 272-273, 1-5.

Stuart, A.J., Lister, A.M., 2007. Patterns of Late Quaternary megafaunal extinctions in Europe and northern Asia. Courier Forschung-Inst. Senckenberg 259, 287 297.

Thévenin, A., 1982. Rochedane. L'azilien, l'Epipaléolithique de l'Est de la France et les civilisations épipaléolithiques de l'Europe occidentale. Thèse. In: Mémoire de la Faculté des Sciences sociales, Ethnologie, 2 vols.. Université des Sciences humaines de Strasbourg, p. 845.

Thévenin, A., Sainty, J., 1998. L'abri de Rochedane à Villars-sous-Damjoux (Doubs). In: Cupillard, C., Richard, A. (Eds.), Les derniers chasseurs-cueilleurs du Massif Jurassien et de ses marges (13000-5500 avant Jésus-Christ). Presses Universitaires Franc-Comtoises, Besançon, pp. 104-105.

van der Plicht, J., Hogg, A., 2006. A note on reporting radiocarbon. Quaternary Geochronology 1, 237-240.

van der Plicht, J., Wijma, S., Aerts, A.T., Pertuisot, M.H., Meijer, H.A.J., 2000. The Groningen AMS facility: status report. Nuclear Instruments and Methods B172. $58-65$. 